NBER WORKING PAPER SERIES

\title{
A STATISTICAL ANALYSIS OF CRIME AGAINST FOREIGNERS IN UNIFIED GERMANY
}

\author{
Alan B. Krueger \\ Jörn-Steffen Pischke \\ Working Paper 5485
NATIONAL BUREAU OF ECONOMIC RESEARCH 1050 Massachusetts Avenue
Cambridge, MA 02138
March 1996

We thank Dietmar Harhoff and Helmut Seitz for helpful discussions. We are grateful to Henning Colsman-Freyberger for able research assistance and to Lisa Krueger for preparing the maps. We thank Dietmar Harhoff, Manfred Kuechler and Martin Wortmann for data and the Institute for Policy Reform and the Sloan Foundation for financial support. The data and computer programs used to generate the main results of the paper are available via anonymous FTP in the GERMANY subdirectory of IRS.PRINCETON.EDU. This paper is part of NBER's research program in Labor Studies. Any opinions expressed are those of the authors and not those of the National Bureau of Economic Research.

(c) 1996 by Alan B. Krueger and Jörn-Steffen Pischke. All rights reserved. Short sections of text, not to exceed two paragraphs, may be quoted without explicit permission provided that full credit, including () notice, is given to the source. 


\title{
A STATISTICAL ANALYSIS OF CRIME AGAINST FOREIGNERS IN UNIFIED GERMANY
}

\begin{abstract}
Germany has experienced a high and rising rate of anti-foreigner violence during the early 1990s. To analyze the determinants of crime against foreigners we assembled a new data set on the number and nature of such crimes at the county level based on newspaper reports. We find significant differences in the patterns of violence in the eastern and western parts of the country. The incidence of anti-foreigner crime is higher in the east and rises with distance from the former west German border. Economic variables like unemployment and wages matter little for the level of crime once location in the east is taken into account. The relative number of foreigners in a country has no relationship with the incidence of ethnic crimes in the west, whereas in the east it has a positive association with the number of crimes per resident and a negative association with the number of crimes per foreign resident.
\end{abstract}

\author{
Alan B. Krueger \\ Department of Economics \\ Princeton University \\ Princeton, NJ 08544 \\ and NBER
}

Jöm-Steffen Pischke Department of Economics Massachusetts Institute of Technology Cambridge, MA 02139 


\section{Introduction}

German unification and the transition to a market economy in former East Germany has been accompanied by a high and rising rate of violence against foreigners. In 1992, the police recorded 6,336 crimes against foreigners, 2,544 of which were violent crimes. The high number of attacks that have occurred during the last few years and their high growth rate highlight the need to understand the determinants of crime against foreigners. In this paper, we seek to determine the correlates of violence against foreigners in Germany at a regional level.

Two main strands of literature on ethnic violence in Germany have surfaced in the past few years. The first, rooted in sociology and social psychology, consists of surveys primarily of youths. These surveys try to evaluate the respondents' attitudes towards foreigners, their political leanings, and their propensities to participate in acts of violence. The goal of these studies is to isolate potential causes for individuals' participation in anti-foreigner crimes (see Schnabel (1993) for a critical review of these studies). Clear conclusions are rare despite the large number of such surveys. The second strand of literature has more of a political science focus, and has tried to determine the degree to which the current increase in violence is related to rising right-wing extremism. Much of this literature is rather conjectural. In an intriguing recent paper, Alber (1994) hypothesizes that, "anti-foreign violence should predominantly occur in regions with a high proportion of immigrants, with high unemployment, and with a local political center that is occupied by conservative and patriotic political elites who do not ostentatiously de-legitimate excessive nationalism." Alber recommends using regional-level data to test these hypotheses. 
Our paper is the first that we are aware of to analyze regional-level data on the incidence of crime against foreigners in Germany. To this end we have assembled a new data set on the number and nature of anti-foreign crime at the county level. Because disaggregated data from police records are not publicly available, we constructed our data set from a comprehensive review of newspaper reports on crime against foreigners. Using regressionbased analyses, we test which economic and demographic variables are associated with the incidence of violent acts against foreigners. Although this approach seems to be novel in the German context, it draws on a large tradition in the American social science literature investigating the determinants of lynchings at the turn of the century, and, for more recent periods, crime rates in general.

Some clear results emerge from our analysis. There are significant differences in the incidence and pattern of the violence in the eastern and western parts of the country. The incidence of anti-foreign violence, either per foreigner or per capita, is greater in the eastern states, and many of the attacks in the east are concentrated in the rural coastal areas and along the Polish border. Economic strain, as measured by high unemployment or low wages, seems to contribute little to the incidence of violence once location is taken into account. This finding is consistent with much of the literature on crime for the U.S. and with the survey evidence for Germany. In particular, Heitmeyer (1992) stresses that even multiple indicators of economic pressures do not help to predict likely involvement in violence at the individual level. We also find no relationship between the percentage of foreigners in a county and the number of attacks in west Germany. This contradicts theories trying to relate crime to criminal opportunities. 
In general, our results are difficult to reconcile with simple economic theories of crime against foreigners. In particular, Alber's plausible hypotheses that crime should be positively associated with the level of immigrants and the rate of unemployment in an area are not supported. A more complex process seems to be at work, perhaps a repercussion of the difficult issues arising from unification between east and west Germany.

The remainder of the paper is organized as follows. Section 2 provides some background on Germany's migration history and the rise of violence against foreigners. It also describes some major events which seem to have played an important role as catalysts for subsequent criminal acts. Section 3 describes our data set. Sections 4 and 5 present our main findings. Section 6 discusses our findings in relation to the previous literature.

\section{The Rise in Anti-Foreigner Violence}

Post World War II Germany continually has had a large inflow of foreigners. Nevertheless, the extent and composition of immigration has changed dramatically over time and has differed considerably between the East and the West. At times, foreigners were actively recruited as guest workers. While the relatively small number of foreign workers from Third World Communist countries were short-term visitors in the East, many of the southern European workers who came to the West during the boom in the 1960s settled permanently, and they still make up the largest group of foreigners in Germany.

Nefarious acts by right-wing extremists increased in both parts of Germany during the 1980s. According to official reports, between 188 and 481 right-wing extremist acts were counted in East Germany for the two year period 1988 and 1989 (Knütter, 1993). During the 
same period, 457 violent right-wing crimes took place in the West (BMI, 1994). In the mid 1980s, right-wing extremist parties began to single out foreigners as targets in their propaganda. The number of violent crimes against foreigners in the West increased from 50 in 1985 to 152 in 1990 (Sippel, 1993).

In October 1990, East and West Germany were unified into a single nation. Economic union was accompanied by mass layoffs and plant closing in the east, leading to depressionlevel unemployment rates. The eastern economy was propped up by massive subsidies from the west. The collapse of other economies in Eastern Europe, the opening of the borders of the former Communist countries, and ethnic conflicts on the Balkan led to greater migration flows into Germany in the early 1990s. By 1991, Germany had a gross annual inflow of more than one million immigrants. In addition, a growing share of the arrivals were asylum seekers. Their numbers grew from 121,000 in 1989 to 256,000 in 1991 and 438,000 in 1992 . Although asylum seekers made up just $10 \%$ of all immigrants (including ethnic German re-settlers) in 1989 , their share grew to $30 \%$ by 1992 .

At the time of unification, foreigners made up about 8 percent of the population in the west. There were relatively few immigrants in the east because most guest workers from the communist period returned home. There was also little reason for economic migrants in the west to look for jobs in the east given the high rate of unemployment there. Nevertheless, the federal government decided that eastern states should bear their fair share of the burden of housing newly arriving asylum seekers, so many former Soviet barracks were converted to homes for asylum seekers. 
Figure 1 displays the number of crimes against foreigners each month, using aggregate data reported by the federal police and a data set that we collected ourselves which is described in detail in the next section. There are several peaks in these data, associated with events which were widely covered by the media. On Tuesday, September 17,1991 , there was a tragic assault against foreigners living in an asylum seeker home in Hoyerswerda in the eastern state of Saxony, about 20 miles from the Polish border. Over this period, the number of antiforeigner attacks increased dramatically, from 104 in August to 961 in October. The number of violent anti-foreigner crimes also rose, from 152 in 1990 to 1257 in 1991 (Sippel, 1993).

There are three other incidents that appear to have served as catalysts for similar bursts in the number of crimes against foreigners. The first are the riots against the Central Intake Station for Asylum Seekers in Rostock-Lichtenhagen in the eastern costal state of Mecklenburg-Vorpommern in late August of 1992. Another spike in the number of crimes occurred two months later when three Turkish residents died in fire bombings of two residences in Mölln, Schleswig-Holstein (west). The next spike is associated with another fire bombing of a Turkish home in Solingen, Northrhine-Westfalia (west) in May 1993, killing tive. In between these events, the number of attacks fell back to lower levels, but remained far above the level in early 1991.

Many large-scale riots, such as the well known riots in Hoyerswerda and Rostock ... and less well known incidents in Wismar, Cottbus, and Quedlinburg -- took place in the cast. These attacks were directed against asylum seekers' homes. And in each case the rioters " were supported by the neighboring German population. The picture in the west is rather different. 
The well known attacks of Mölln and Solingen were fire bombings by small groups of individuals.

It is important to place the magnitude of the number of crimes against foreigners in Germany in perspective. A total of 13,000 criminal acts were committed in 1992 and 1993. Many of these crimes were nonviolent, including offenses like propaganda and threats. In 1992, the worst post-War year of anti-foreign violence in Germany, there were 2,544 violent crimes perpetrated against foreigners. This translates into a violent crime rate against foreigners of about 3 per 100,000 residents. Overall, there were a total of 150,000 violent crimes recorded in Germany in 1992, for a crime rate of 188 per 100,000 residents. By contrast, the violent crime rate for the U.S. was 758 per 100,000 in 1991 . There have been widely publicized incidents of ethnic crimes in other European countries in the early 1990s as well. Although statistics on the rate of ethnic crimes are difficult to compare across countries, it seems clear that the level of crime is much lower in most other countries with the exception of the UK, which has a similar number of racial crimes as Germany (Alber, 1994). Understanding the determinants of anti-foreigner crime in Germany would therefore seem to be a priority.

\section{The Newspaper Data Set}

Official police data on the extent of crime against foreigners are not available below the level of states. Unified Germany has 16 states, which makes a state-level analysis rather remote and subject to small sample concerns. As a consequence, we have assembled a new county-level data set on the number of incidents of crime against foreigners derived from 
newspaper and magazine reports. We refer to this data set as the Newspaper Data Set. This methodology has a long history in sociology, as much of the literature on lynchings and urban racial conflicts in the U.S. is based on newspaper reports (see e.g. Danzger, 1975, Inverarity, 1976, and Olzak, 1989).

Our data set is derived from a list originally compiled by the Archiv fuir Sozialpolitik in Frankfurt, Germany. The Archiv collected this list from several German daily and weekly newspapers and magazines. ${ }^{1}$ The dailies are typically regional newspapers with an extensive national circulation and coverage; and the biggest papers are included. The German newspaper market is much more concentrated than the U.S. market, so these publications provide fairly comprehensive coverage of the entire nation. ${ }^{2}$

The list contains short summaries of each reported event. The contents of this list were coded for us in a consistent fashion by "Research on Demand" in Berkeley, CA, and the coding was checked by us. The final sample consists of a total of 1,056 incidents which occurred between January 1991 and June $1993 .^{3}$ For most of these events we know the date, location, the type of crime, and often a description of the victims. In a subset of cases we have more detailed information on the number of victims and the number of perpetrators. The following

'The number of newspapers varied somewhat over time. In late 1992, the newspapers included: Ärztezeitung. Frankfurter Allgemeine, Frankfurter Rundschau, Neue Züricher Zeitung, Süddeutsche Zeitung, Tagesspiegel, die tageszeitung, Bayernkurier, Deutsches Allgemeines Sonntagsblatt, Freitag, Hamburger Rundschau, Parlament Profil, Spiegel, Woche im Bundestag. and Zeit.

${ }^{2}$ The Archiv für Sozialpolitik experimented with including more papers at some time but found that this resulted in only a small increase in the number of reports.

${ }^{3}$ The original data set contained 1,218 events. We eliminated incidents in which we could not determine the location or date, incidents that were double entered, and incidents that did not involve anti-foreign violence. 
excerpt gives a sample of the incidents reported on a randomly selected date (October 11, 1991), and describes the nature of the information available to us.

\section{Sample of Incidents for Friday, October 11, 1991}

- Two skin heads shatter a window of a dormitory for foreign workers in Rangsdorf/Zossen County.

- Three young Germans throw rocks at an asylum seeker in Erlensee near Hanau.

- A Nigerian is beaten severely by a 19 year old German in downtown Saarbrücken.

- Also in Saarbrücken, according to his own account, a refugee from Sri Lanka is abducted after getting off a bus, sedated, and thrown on train tracks. He is found by police near the tracks in the evening. Blood stains show that he has been run over by a train. His right leg has to be amputated under the hip in an emergency medical procedure.

We aggregated the events in our database to the level of counties. The sample consists of data on 543 counties. Every incident is assigned the same weight, independently of the severity of the crime and the number of perpetrators involved. For example, the riots in Rostock are counted as one incident, just as the case of two skin heads shattering the window in a dormitory for foreign workers mentioned in the sample from October 11, 1991 above. This is clearly problematic. To assess whether the severity of the crime matters we provide separate analyses for our full sample and for serious crimes (murder and arson) only.

We provide two checks on the accuracy of the newspaper-based database. First, we aggregated our Newspaper data set to the state level, and computed the number of incidents per person in the state. We then compared the ofirial state-level police anti-foreigner crime 
rate to this state-level Newspaper-based crime rate. The two sources of data are positively correlated, with a Pearson correlation coefficient of 0.54 . A regression of the number of incidents from the police data on the number of incidents from the Newspaper data and an intercept yields a coefficient of 1.55 (std. error of .65 ), which suggests that the 1.55 police crimes are registered for each incident reported in the newspaper. ${ }^{4}$ If we add a dummy variable to this regression indicating whether the state is in the east or west, the dummy has a statistically insignificant effect while the Newspaper data incident rate continues to be significant. This suggests that the Newspaper data do not have an obvious east-west regional bias. Although we would prefer to find a higher correlation between the police and Newspaper data, these results suggest that the Newspaper data set conveys some signal on the frequency of crimes against foreigners.

Second, we formed nationwide monthly totals of the Newspaper data to compare to the national numbers released by the police. This comparison is shown in Figure 1. Three conclusions can be drawn from the figure. First, we count only about one tenth of all the incidents per month recorded by the police. This is not surprising, as many of the crimes the police record are relatively minor violations that are not reported in the press. Second, our data track the temporal pattern of the police data rather well. The correlation between the two series is 0.75 . Interestingly, we do not see over reporting in the press after the events of Hoyerswerda, Rostock, and Solingen. Third, after the Rostock riots our data tend to record a much smaller fraction of crimes than the police data. When we limit the Newspaper sample to violent crimes, however, we do not observe the same drop off.

${ }^{4}$ The intercept term in this regression has a coefficient of 6 
We also compared our Newspaper data to the police data by the type of crime committed. We grouped the data into four major categories: murder and attempted murder; arson; assault and battery; and others which primarily include unlawful entry, weapons offenses, threats, and graffiti. ${ }^{5}$ Over 40 percent of the incidents reported in the newspaper data involve murder or arson, compared to just 9 percent of the police data. Not surprisingly, the newspaper coverage appears to be more complete for the most serious crimes. Consequently, below we estimate models using all crimes as well as the subset of more serious crimes (murder and arson).

One might question whether the county is the right level of observation for this type of study. There are 543 counties in Germany, 215 in the east and 328 in the west, with an average population of 147,000 . Small counties, however, can have a population of only 20,000. Perpetrators in crimes against foreigners may not necessarily come from the locality where the crime took place. However, according to studies of police files, most of the perpetrators are locals. For example, Raisch (1994) reports that for the eastern state of Saxony, $90 \%$ of suspects live in the town of the crime or within 20 kilometers. He also notes that 77 of the 82 suspects investigated by the police for participation in the Hoyerswerda riots are from that county or the neighboring areas, and the remaining five had family ties in Hoyerswerda. These results suggest that the county unit may be an appropriate level of observation."

\footnotetext{
${ }^{5}$ The police definition of murder is narrower than ours, so there are actually more mur lers in the newspaper data than in the police data.

${ }^{6}$ Leenen (1992) cites similar results for Northrhine-Westfalia.
} 


\section{Variables}

Our covariates include several county-level measures of socioeconomic conditions, such as the fraction of foreigners and the unemployment rate. These are taken from "Aktuelle Daten zur Entwicklung der Städte, Kreise und Gemeinden 1989/90" (Current Data on the Development of the Cities, Counties, and Towns 1989/90), published by the Bundesforschungsanstalt für Landeskunde und Raumordnung (BfLR, 1992), and subsequently updated by the same institute. Unfortunately, more limited data are available for east Germany, and not all regressors pertain to the same date.

Since counties are of unequal size we tried two alternative approaches to scaling the dependent variable. First, we used the number of incidents of anti-foreign crime per 100,000 persons (the crime rate). This is the typical variable analyzed in regional studies of crime in the sociology literature (e.g., Land, McCall, and Cohen, 1990). Second, we used the number of incidents divided by the number of foreigners residing in the county. In this case the dependent variable could be interpreted as a "victimization rate." It turns out that the results are qualitatively similar with either variable.

Our main regressors are the unemployment rate, the share of foreigners in the county, a dummy variable for being located in the east, and several variables describing the degree of urbanization of the county. The unemployment rate is based on the number of individuals registered with the local unemployment insurance office in September 1992. It does not reflect discouraged workers, who have dropped out of the labor force, or unemployed workers who are actively searching for work but do not qualify for UI benefits. 
The unemployment rate alone may not be a good indicator of economic conditions in a county. In particular, easterners living closer to the former western border can commute more easily to jobs in the west. Moreover, social attitudes and police enforcement may be different closer to the west. Therefore, we created an additional variable for counties in the east: the distance from the former west German border. This is measured by the straight line (Euclidean) distance between the geographic center of a county and the closest county in the west. ${ }^{7}$ In each case, we constructed the distance to the west German mainland excluding West Berlin. For west German counties this variable is set to zero.

The number of foreigners in a county is the number of those registered in a particular region as of December 1991. This includes foreign workers, unless they are in Germany for less than three months (e.g. seasonal workers), and asylum seekers. Asylum seekers typically register within the first month of their arrival in Germany, but the time lags differ across states. $^{8}$ Thus, the small number of asylum seekers whose application is denied very rapidly and who leave the country may not be counted. Ethnic German immigrants (primarily from Russia, Romania, and Poland) are also not counted since they become German citizens upon arrival. Also excluded are foreign military personnel. This may especially be a problem for Soviet soldiers in the east. Nevertheless, the foreign share variable should give a reasonably accurate measure of the fraction of foreigners in a county.

We include a variety of regressors to describe the degree of urbanization. Most importantly, four dummy variables for the degree of urbanization of the region (not necessarily

${ }^{7}$ Dietmar Harhoff provided the geographic coordinates of the counties to us.

${ }^{8}$ Based on personal communication with the Federal Ministry of the Interior. 
the county itself). These are major metropolitan areas (urban), regions with some urbanization (moderately urban), rural region not on the periphery (moderately rural) and rural region on the periphery (rural). ${ }^{9}$ We also include a dummy variable indicating whether the county is an independent city (called "Kreissatdt" in German) and the population per square kilometer. Finally, we include the travel time by car (in minutes) to the nearest major metropolitan area.

For the western counties more variables are available. We use the fractions of high skilled workers (at least college; the "Fachhochschule" or "Universität" level) and of low skilled workers (no qualification beyond secondary school, such as an apprenticeship). We also intended to include a measure of the proportion of young adults in the population, as this group represents most of the perpetrators. However, the only variable available is the fraction age 15 to 49 . Finally, we include the logarithm of the average manufacturing wage (manufacturing payroll divided by employment).

\section{A Descriptive Analysis}

We first examine basic patterns of crime against foreigners. Table 1 provides descriptive statistics of the main variables in our data set. Most of the foreigners are concentrated in the western part of Germany. The share of the population that is foreign in the east is less than one percent. In both parts of the country this share has been increasing since unification.

The total number of incidents of crime against foreigners in our data set is 1,056 .

Figure 2 displays the number of incidents per county in a histogram. The distribution is highly

\footnotetext{
${ }^{9}$ These are the four "siedlungsstrukturelle Regionstypen" of the BfLR.
} 
skewed, with zero or one incident being the most common occurrences. More crimes against foreigners occurred in the west, but it must be recalled that the east has only a quarter as many people as the west. This leads to an incident rate -- the number of incidents per 100,000 population -- that is more than three times as high in the east. With such a low share of foreigners living in the east, the number of incidents per foreigner is even more skewed -almost fifty times higher in the east than in the west. The mean unemployment rate is about twice as high in the east than in the west. In addition, the eastern unemployment rate probably understates the true employment conditions in the east because of large scale government subsidy programs.

The regional dispersion in these variables can be seen, more clearly in Maps 1 through 4. Map 1 shows the rate of incidence of crimes against foreigners per 100,000 residents. There are numerous white spots on the map, indicating counties without incidents in our data. Within eastern Germany, the crime rates are not only higher on average but the counties with high rates of crime tend to be clustered along the coast in the north and along the eastern border with Poland. Map 2, which shows the number anti-foreign crimes per 1,000 foreigners, displays a similar pattern. Both maps show a fairly strong spatial correlation in anti-foreigner crime rates, with nearby counties displaying similar crime rates.

The unemployment rates in various regions are shown in Map 3. This map essentially outlines the eastern and western parts of the country. Nevertheless, it is clear that there are differences in economic conditions within the eastern and western regions: areas of Saxony, Brandenburg, and Sachsen-Anhalt are doing better than other eastern counties, while in the west, the northern coast, Ruhr, and Saar and Pfalz areas have relatively high unemployment. 
Map 4 shows the density of foreigners. The foreign population is clustered in the southwestern state of Baden-Württemberg (home of much of the machine tool and car industry), along the Rhine valley and in the Ruhr area (where west Germany's heavy industry is located). This pattern is the result of guest worker recruitment in the 1960 s, when workers where needed primarily in the metal manufacturing sectors. In the east, only Berlin has a high concentration of immigrants.

The east and the west differ in the national composition of immigrants, as well as in their absolute numbers. The dominant groups in the west are Turks, Yugoslavs, Italians, and Greeks, many of whom are guest workers who have become long-term or permanent residents. The foreigners in the east are predominantly eastern Europeans, who make up much of the recent arrivals from abroad. Table 2 shows that these patterns are also reflected in the nationality of the victims. ${ }^{10}$ In the east, $46 \%$ of the victims come from Eastern Europe and about $22 \%$ from communist (or former communist) developing countries. Only $8 \%$ of the victims are Turks. In the west, Turks are the largest group of victims $(40 \%)$, slightly more than their share among the foreign population. Other southern Europeans make up $10 \%$ of the victims, and eastern Europeans make up 15\%. Africans and Asians, who make up a imall fraction of foreigners in the population, are clearly over represented among the victims

Table 2 indicates that foreigners do not randomly fall victim to anti-foreign attach s. hut that this type of crime is disproportionately directed at groups who differ more from (icrmuns in terms of color, race, or religion, or who are among the most recent arrivals. Moreoser. thice is a higher incidence of attacks against asylum seekers than against foreign workers in fincral.

${ }^{10} \mathrm{We}$ know the ethnicity of victims in only 378 out of the 1,056 incidents. 
Fully $54 \%$ of all incidents reported in the east were attacks against asylum seekers, and $43 \%$ were classified as such in the west.

\section{Regression Analysis of Regional Patterns of Crime}

We relate the incidence of crime against foreigners to measures of the socioeconomic characteristics of the county where the incident took place and other variables. Several specifications and estimation techniques are used. We initially estimated Ordinary Least Squares (OLS) regressions using incidents per 100,000 residents or incidents per 1,000 foreigners as the dependent variable. We then calculated Moran I statistics to test for spatial autocorrelation among the errors and found a significant degree of error correlation across neighboring counties." We therefore report results which adjust for spatial autocorrelation in the error term.

Specifically, we estimate the following model:

$$
\begin{gathered}
y=X \beta+u \\
u=\lambda W u+\varepsilon
\end{gathered}
$$

where $\mathrm{y}$ is a vector of the relative number of incidents, $\mathrm{X}$ is a matrix of covariates, $\mathrm{u}$ is a spatially correlated error vector, and $\mathrm{W}$ is a scaled $\mathrm{n} \times \mathrm{n}$ contiguity matrix which parameterizes which counties are considered neighbors. A typical entry in an unscaled version of the W matrix is $w_{i j}=1$ if counties $i$ and $j$ share a common border and 0 otherwise (and $w_{i i}=0$ ). However, $W$ is rescaled so that each row sums to one, i.e. $w_{i j}=1 / 5$ if county $i$ borders on five other counties. This rescaling crudely allows for counties with only little overlap to have

\footnotetext{
${ }^{11}$ ee, e.g., Anselin (1988) for details on the Moran I test.
} 
comparatively less influence. The parameter $\lambda$ is a measure of the degree of spatial correlation. If $\lambda=0$, there is no spatial autocorrelation.

The parameters $\beta, \lambda$, and $\sigma_{\varepsilon}$ are estimated jointly by Maximum Likelihood, which in this case is identical to iterated feasible GLS if the estimation step for $\lambda$ uses the concentrated likelihood. Define $A=1-\lambda W$. The $\log$ Likelihood function for the model is:

$$
\log \mathrm{L}=-.5 \mathrm{n} \ln (\pi)+\ln |\mathrm{A}|-.5\left(\mathrm{v}^{\prime} \mathrm{v}\right) / \sigma_{\varepsilon}^{2}
$$

where $v=A(y-X ß)$.

$\underline{\text { Results }}$

Table 3 presents regressions for the pooled sample of all German counties using incidents per 100,000 residents or incidents per 1,000 foreigners as the dependent variable. ${ }^{12}$ The model in column (1) includes as explanatory variables: the unemployment rate, the foreign share and a variety of indicators of the degree of urbanization. In these regressions the unemployment rate has a positive and highly significant coefficient with a t-ratio of about 3 . However, this coefficient merely reflects the higher level of crime in the eastern part of the country. Once we also include a dummy variable that equals one for counties located in the west in column (2), the unemployment rate has a statistically insignificant and negative effect. Furthermore, the coefficient on the foreign share becomes positive but remains insignificant. Contrary to Alber's hypothesis, there is no evidence that within the two parts of the country

${ }^{12}$ Notice that there are two counties in the east with less than $0.1 \%$ of foreigners. Because these appear as zeros in our data we could not form the ratio of incidents to the number of foreigners. These two counties are omitted from the set of regressions using incidents per $1,0()$ soreigners. 
higher unemployment is associated with more crime. Furthermore, the coefficient on the west dummy is larger than the raw difference in the crime incidence rate between the east and the west $(3.7$ versus 2.2$)$.

Column (3) adds two distance variables as regressors: the distance from the western border for the eastern counties and the travel time by car to the next metropolitan area. The distance to the west has a highly significant and large coefficient. It implies that for every 100 $\mathrm{km}$ of distance from the western border the number of incidents increases by 2.4 per 100,000 residents. This is much larger than the mean of the dependent variable (1.3). ${ }^{13}$ Distance from a metropolitan area also increases the crime rate. However, this effect is difficult to interpret with the other urbanization variables in the regression. The spatial correlation coefficient $(\lambda)$ between neighboring counties is 0.39 in the most parsimonious specification in column (1) but drops to about half that size when the distance variables are added in column (3).

The last three columns of Table 3 use the number of incidents per 1,000 foreigners as the dependent variable. The basic pattern of results is the same as in columns (1) through (3), but the effects tend to be somewhat less pronounced. Nevertheless, there is no evidence of a positive association between the unemployment rate and victimization rates within the regions. We also entered the foreign share of the population as an explanatory variable in these regressions. The positive coefficient on this variable implies that, within regions, the victimization rate tends to be higher in areas with relatively more foreigners. Unlike the

${ }^{13}$ Such a pattern is unlikely to result from reporting bias. More incidents are reported further away from the west $w$ here most of the newspapers are located. 
incidence regressions, spatial autocorrelation of the errors is quite modest in the victimization rate regressions.

We should note that our coefficient estimates are qualitatively similar when we estimate OLS regressions instead of the Maximum Likelihood models in Table 3. The standard errors of the estimates are about 10 to 20 percent greater in the models that adjust for spatially correlated errors, however. Additionally, we estimated an alternative model in which we allowed the spatial correlation to enter directly through the adjacent county's crime rate (specifically, we added Wy as a regressor and estimated the model by maximum likelihood) rather than through the adjacent county's residuals. Estimates from these models also yielded qualitatively similar results.

Another issue concerns the representativeness of the crime data. Despite the findings of our earlier comparison of the Newspaper and police data, one may question whether the Newspaper data systematically miss crimes in some regions. For example, the newspapers and wire services tend to be located in major cities, and these cities may be covered more thoroughly than other areas. We have two additional pieces of evidence that make this seem unlikely. First, all our newspapers are located in the west whereas almost half the incidents are reported to be in the east. Furthermore, within the east most events took place in rural areas, which we would expect to be covered less comprehensively. Secondly, following Danzger (1975), we included a dummy variable for the presence of a German Press Agency (dpa) office in each county in our regressions. ${ }^{14}$ The dpa is Germany's largest wire news service. The coefficient on this dummy was small and statistically insignificant.

${ }^{14}$ We thank Martin Wortmann for pr ividing the list of dpa offices to us. 
In view of the large differences in crime and victimization rates in the east and west and our inability to account for these differences with variables such as the unemployment rate or percent foreign, we present separate regressions for the east and the west in Table 4. Columns (1) and (2), and (5) and (6) report comparable specifications for the east and the west; the other columns add regressors that are only available for parts of the country. Pronounced differences exist in the correlates of violence in the two parts of the country.

The coefficient on the unemployment rate in the east is even more negative and marginally significant in all specifications. The coefficient on percent foreign rises to about 2 in the crime rate regressions, meaning that a 1 percentage point increase in the percent foreign is associated with two more attacks per 100,000 residents. In the victimization rate regressions the coefficient on percent foreign is now negative, unlike in the pooled regression. This suggests that a higher concentration of foreigners leads to a lower rate of victimization.

The results for the west are quite different. A Chow-test for the equality of all coefficients in columns (1) and (2) yields an F-statistic of 13.1, which is statistically significant at the .01 level. No regressor, apart from the urbanization measures, is individually significant in the west. Despite the fact that the percentage of foreigners varies substantially from below $2 \%$ in rural areas of eastern Bavaria or near the North Sea coast to $25 \%$ in Frankfurt. it has an insignificant influence on the number of crimes per resident. Column (4) adds sercrsl variables, including qualifications, the fraction of adults between 15 and 49 , and the manufacturing wage. None of these variables is individually statistically significant.

Urbanization is the only strong predictor of anti-foreign violence in the west: crime ratis are highest in the major metropolitan areas. The coefficients in Table 4 are diflicult in 
interpret directly since the population density, dummies for urbanization and city-counties, and travel time all capture effects related to urbanization. If we only use the four exclusive dummy variables for degree of urbanization we find that a major center has about 0.5 more incidents per 100,000 residents than a rural area, which is a large difference given that the mean of the dependent variable is 0.9 . Interestingly, the pattern by urbanization is exactly the reverse in the east; in the east crime against foreigners is concentrated in rural areas, which have 4.1 more incidents than major cities.

Table 5 reports corresponding results using the subset of serious crimes (homicide and arson) as the dependent variable. The coefficients tend to be lower due to the lower number of total crimes. In all other respects, the qualitative results differ very little from those in Table 4.

\section{Alternative Models}

The regressions presented so far neglect the fact that a substantial number of counties had no incidents of crime against foreigners in our data set (see Figure 2). This censoring of the data may bias the maximum likelihood estimates, which assume normality. We tried several alternative estimation strategies to explore the robustness of the results. Because of the censoring, we cannot easily adjust for spatial autocorrelation with these alternative estimators. But since the spatial correlation of the errors is rather weak in the east, and does not seem critical for the results in the west, this is probably not a major limitation. 
First, and most directly comparable to the previous models, we estimated Tobit models allowing for a censored dependent variable at zero. This yielded very similar results for both the incidence rate and victimization rate.

Our second approach is to use the number of crimes directly as the dependent variable, rather than scaling it by the population or the number of foreigners. In this case, the model is most sensibly treated as a count data model because the number of crimes in each county is an integer and typically small. Table 6 presents estimates of both a Poisson and a negative binomial model. The negative binomial is a Gamma-mixture of Poissons and therefore nests the Poisson model. In each case, the Poisson specification is rejected at the $1 \%$ level in favor of the more general negative binomial model. In these count models we also add the log of the population in the county as a regressor to account for scale. In the negative binomial model this variable has a coefficient insignificantly different from one, which is expected if population only measures scale but has no other influence on the crime rate. In general, the results for both the Poisson and negative binomial specifications are similar to those obtained from the OLS models in Table 4. Thus, we conclude the results are fairly robust to these alterative modelling assumptions.

\section{Discussion and Relation to the Literature}

Our analysis supports several tentative conclusions. First, anti-foreigner violence appears to differ in important respects between east and west Germany. The incidence rate of anti-foreign crime is much greater in the east. In the east, anti-foreign crime is more common in the rural areas. In the west, anti-foreign crime is more common in urban areas. Within the 
east we find that the incidence of crime against foreigners per capita rises with the fraction of foreigners in the county, but there is no relationship between these variables in the west.

Second, contrary to our expectations and Alber's (1993) hypothesis, we find that the incidence of anti-foreign crime is unrelated to the unemployment rate in an area. This finding is consistent, however, with police records on suspects and survey studies of youths. According to BMI (1994), for example, $11.3 \%$ of suspects investigated from 1991 to 1993 were unemployed. This is not much greater than the unemployment rate for the country as a whole. Furthermore, the fraction of unemployed perpetrators does not seem to be much higher in the east (see e.g. Raisch, 1994). This finding may partly be explained by the fact that the perpetrators are typically very young, more than $60 \%$ are age 20 or below, so that a significant fraction are still in school. Surveys of youths also yield a comparable result, that difficult personal economic conditions are not a predictor for violent tendencies among those surveyed (see, e.g., Schnabel, 1993).

Interestingly, regional and time-series analyses of violent crime in the U.S. also find crime to be unrelated to the unemployment rate. For example, Land, McCall, and Cohen, (1990) report that typical cross-sectional studies at the state, SMSA, or city level for the U.S. have found either no or a weak, negative relationship between the homicide rate and the local unemployment rate.

Third, the level of violence in the east is higher in counties that are located further from the western border, other things being equal. There are at least two plausible explanations for this finding. First, because it is easier to commute to the west if the county is near the west. and economic opportunities are greater for commuters, this variable may reflect economic 
conditions. Second, the far eastern states may be more insulated and less exposed to foreigners and western law and order. The variable may thus reflect differences in societal values and legal institutions. The fact that the distance variable was significant after we controlled for travel time to a major metropolitan area, or distance to the nearest county with under a $5 \%$ unemployment rate, provides some weak support for the latter hypothesis.

\section{Conclusion}

A wave of hostility and violence against foreigners has shaken Germany since unification in 1990 . While the number of such crimes had increased already in the late 1980 s, there was a tenfold increase from 1990 to 1991 alone. The sharp rise in violence, and the political nature of the attacks, make this a problem of particular concern. Although social scientists have yet to advance a coherent theory for this rise in violence, our analysis, as well as previous work, has uncovered a number of important patterns. The rates of violence have been higher in the eastern part of the country despite the fact that very few foreigners actually live there. Foreigners, and in particular asylum seekers, had been singled out as the target of right wing propaganda, alleging them to be responsible for many of Germany's social problems.

We feel relatively confident in ruling out a direct connection between the violence and the poor economic conditions in the east. In particular, we find no connection between the incidence of crime and the unemployment rate or the wage rate. This confirms survey results indicating that personal economic strain alone is not a strong predictor of violent tendencies. It is also consistent with findings on crime more generally. This does not mean that the 
economic conditions in the east have no impact on crime against foreigners at all, but the connection is likely to be more complex.

Lastly, we document some clear differences in anti-foreign crime between the east and the west. The higher incidence of crime in the east is consistent with survey findings that show that many youth in the east feel more inclined towards violence as a means of solving social conflicts. But not just the levels differ, the patterns differ as well. Crime against foreigners in the east is mostly concentrated in rural areas, whereas it is mostly concentrated in metropolitan areas in the west. Interestingly, we do not find that any other important covariates explain the occurrence of ethnic crime in the west. Once the rising wave of violence and the surrounding political climate seemed to generate enough legitimacy for this type of behavior, it broke out uniformly, largely independent of specific local conditions. This makes preventing and fighting such crime a difficult task, and continues to provide a challenge to social scientists to identify the causes more clearly. 


\section{References}

Alber, Jens (1994) "Towards Explaining Anti-Foreigner Violence in Germany." WP No. 53, Center for European Studies, Harvard University

Anselin, Luc (1988) Spatial Econometrics: Methods and Models. Dordrecht: Kluwer Academic Publishers.

Bundesforschungsanstalt für Landeskunde und Raumordnung (BfLR) (1992) Laufende Raumbeobachtung: Aktuelle Daten zur Entwicklung der Städte, Kreise und Gemeinden 1989/90, Materialen zur Raumentwicklung Heft 47, Bonn: BfLR

Bundesministerium des Inneren (BMI) (1994) Verfassungsschutzbericht 1993, Bonn: BMI

Danzger, M. Herbert (1975) "Validating conflict data," American Sociological Review 40, 570-584

Heitmeyer, W. (1992) Die Bielefelder Rechtsextremismus Studie: Erste Langzeituntersuchung zur Sozialisation männlicher Jugendlicher, Weinheim/München

Inverarity, James M. (1976) "Populism and lynching in Louisiana, 1889-1896: A test of Erickson's theory of the relationship between boundary crises and repressive justice," American Sociological Review 41, 262-280

Knütter, Hans-Helmuth "Die Entwicklung des Rechtsextremismus in Deutschland. Historische, gesellschaftliche und psychologische Bedingungen seines Entstehens," in: BMI (ed.) Extremismus und Gewalt, vol. 1, Bonn: BMI, 7-34

Land, Kenneth C., Patricia L. McCall, and Lawrence E. Cohen (1990) "Structural covariates of homicide rates: Are there any invariances across time and social space?" American Journal of Sociology 95, 922-963

Leenen, Wolf Rainer (1992) "Ausländerfeindlichkeit in Deutschland. Politischer Rechtsruck oder Politikversagen?" Deutschland Archiv 25, 1039-1054

Olzak, Susan (1989) "Labor unrest, immigration, and ethnic conflict in urban America, 18801914," American Journal of Sociology 94, 1303-1333

Raisch, Peter (1994) "Bekämpfung rechtsorientierter Gewalttaten im Freistaat Sachsen Einsatz der Sonderkommission Rechtsextremismus (Soko 'Rex') des LKA Sachsen," in: Alfred Hoffmann (ed.) Fremdenfeindlichkeit in Deutschland, Symposium der Fakultät für Pädagogik, Universität der Bundeswehr, München, 61-75 
Sippel, Heinrich (1993) "Rechtsextremismus in Deutschland. Eine Lagedarstellung," in: BMI (ed.) Extremismus und Gewalt, vol. 1, Bonn: BMI, 35-52

Schnabel, Kai Uwe (1993) "Ausländerfeindlichkeit bei Jugendlichen in Deutschland. Eine Synopse empirischer Befunde seit 1990," Zeitschrift für Pädagogik 39, 799-822 


\section{Map 1}

\section{Number of Incidents of Crime Against Foreigners per 100,000 Residents, County Level}

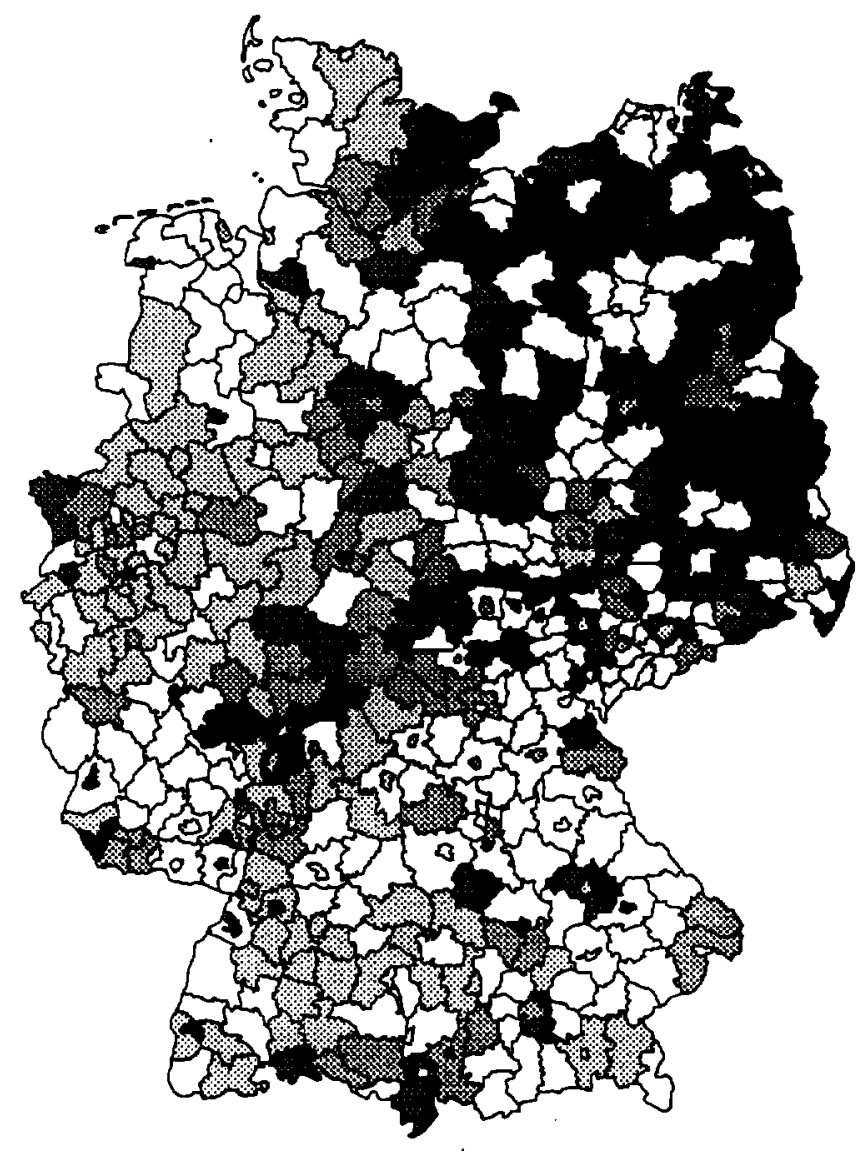

Legend

$\begin{array}{lll}\square & 3.75 \text { to } 34 & (81) \\ 1.75 \text { to } 3.75 & (78) \\ 1 \text { to } 1.75 & (76) \\ 0.15 \text { to } 1 & (92) \\ \square & 0.0 & \end{array}$




\section{Map 2}

\section{Number of Incidents of Crime Against Foreigners per 1,000 Foreigners, County Level}

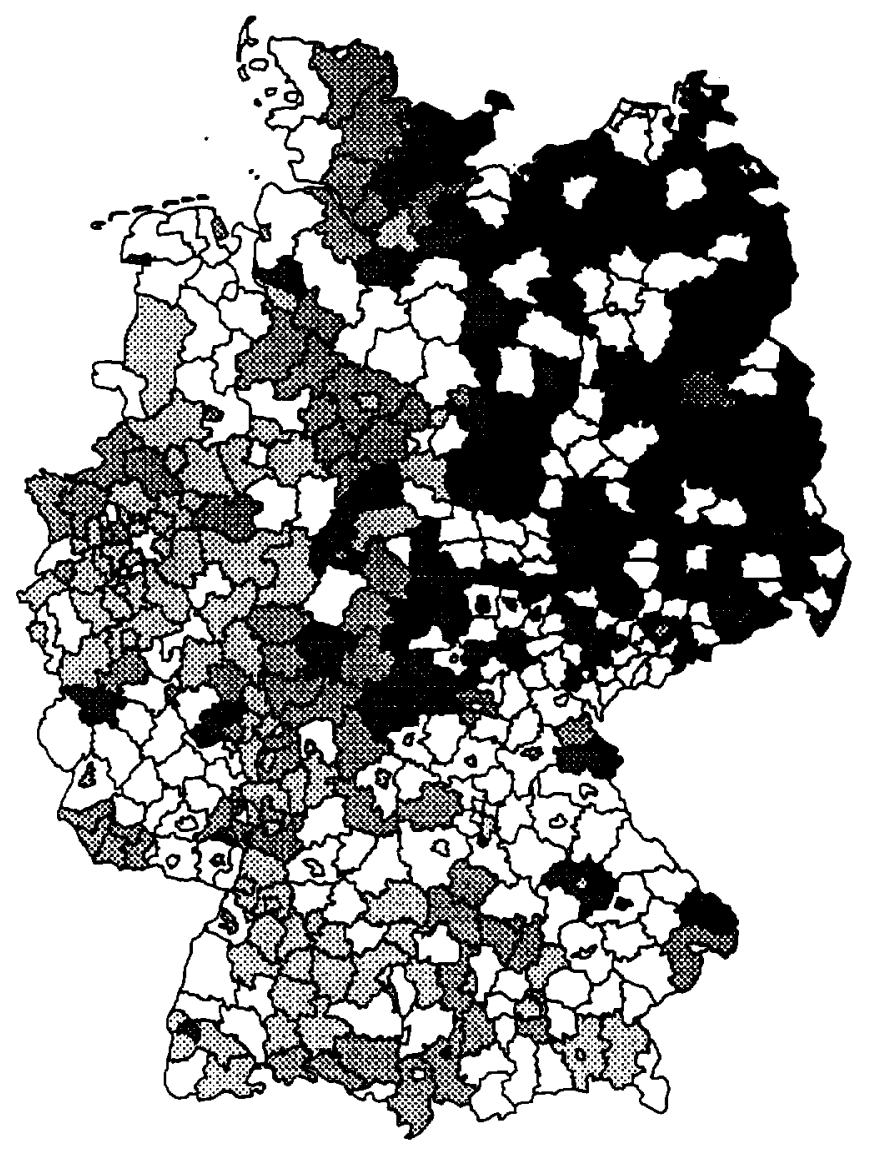

Legend

$\begin{array}{llllr}6 & 6 & \text { to } 339 & (82) \\ 0.5 & \text { to } & 6 & (79) \\ 0.15 & \text { to } & 0.5 & (80) \\ & 0.001 \text { to } & 0.15 & (86) \\ \square & 0.0 \text { to } & 0.001 & (216)\end{array}$


Map 3

\author{
Unemployment Rate \\ by County (Sept. 1992)
}

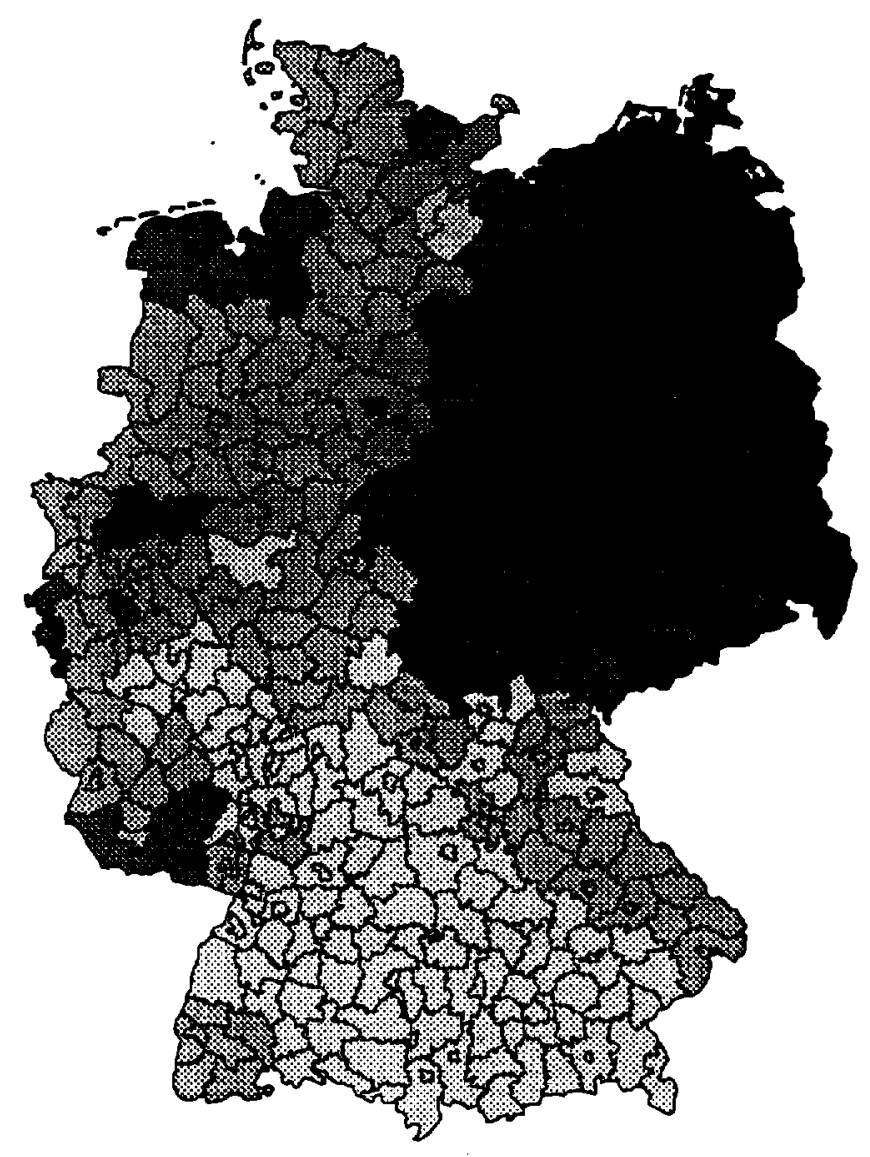

Legend

$\begin{array}{rrr}14.2 \text { to } 19 & (139) \\ 8.2 \text { to } 14.2 & (133) \\ 5.2 \text { to } 8.2 & (137) \\ \quad 2.5 \text { to } & 5.2 & (134)\end{array}$




\section{Map 4 \\ Foreigners as a Percent of County Population in 1991}

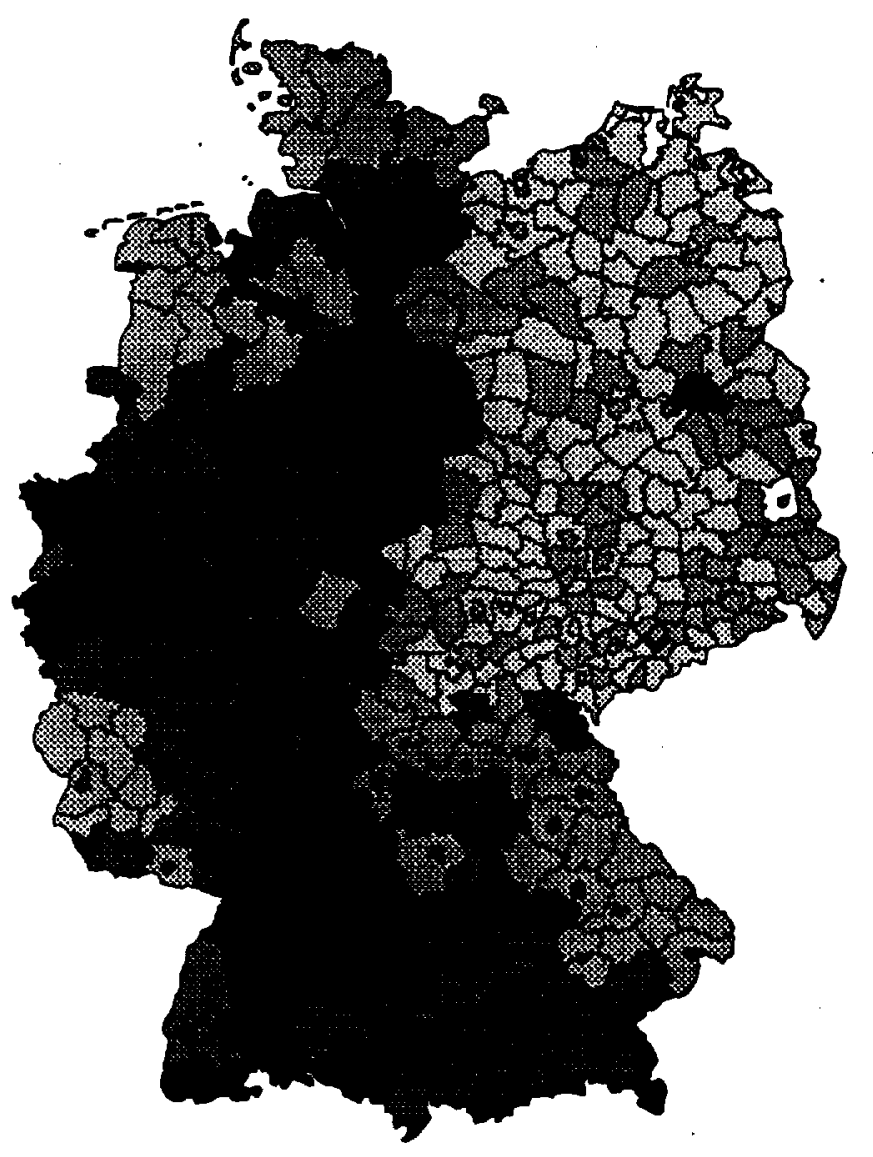

Legend

- 7.1 to 25.7 (136)

- 3.2 to 7.1 (136)

0.5 to 3.2 (141)

0.1 to $0.5 \quad(128)$

$\square \quad 0.0$ to $0.1 \quad$ (2) 
Figure 1

Number of Crimes Against Foreigners

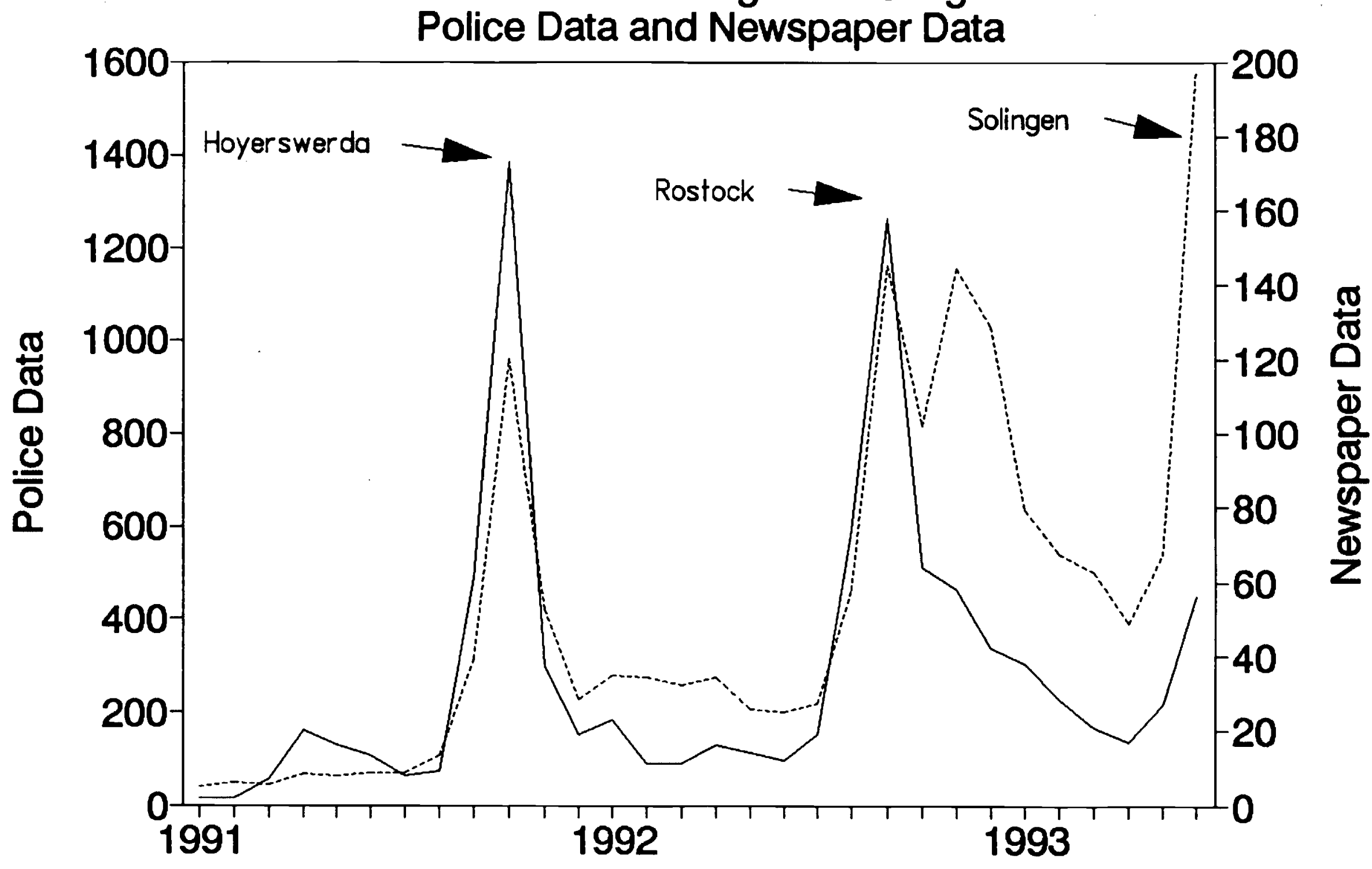

Police Data Newspaper Data 


\section{Figure 2}

Histogram of the Number of Incidents per County

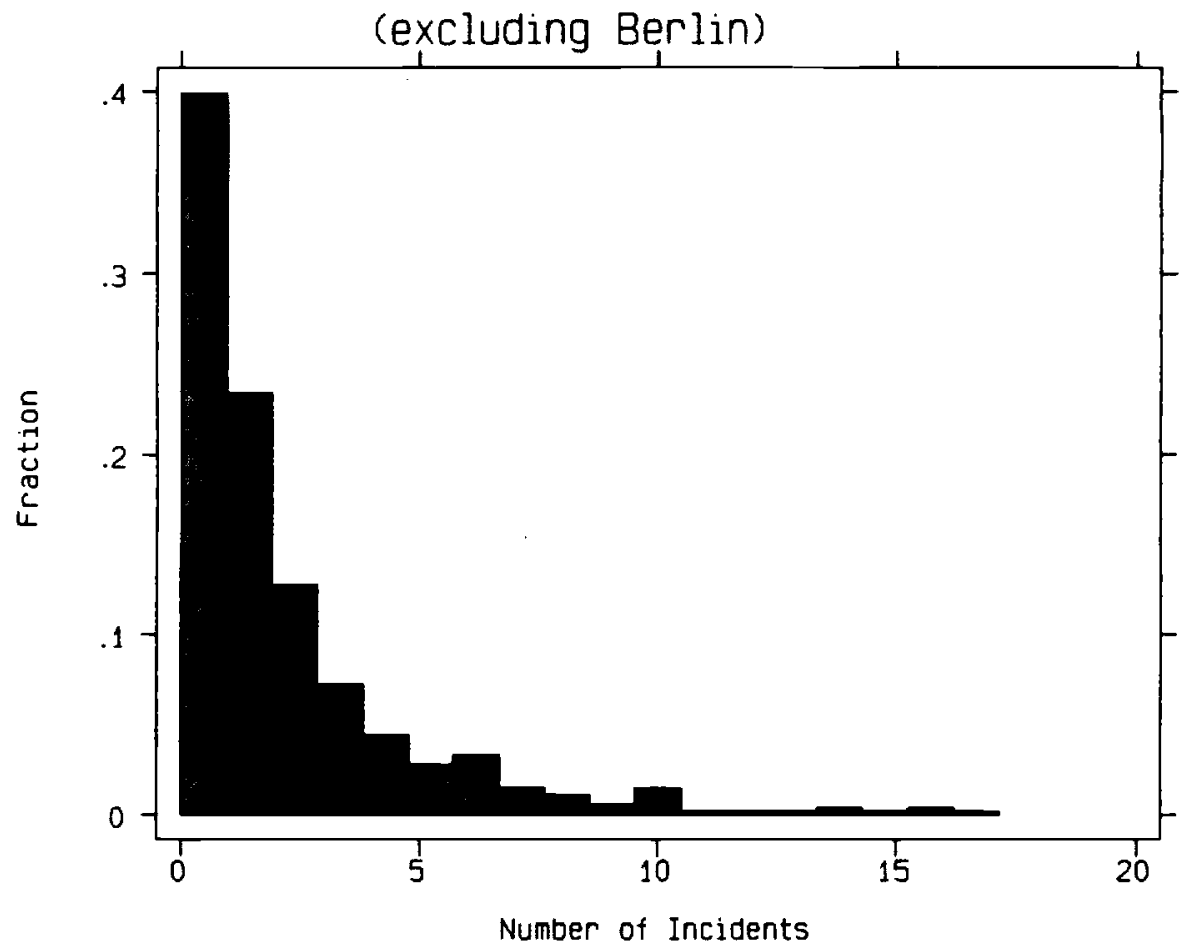

Note: The number of incidents in Berlin was 56 . 
Table 1

Descriptive Statistics"

East $\underline{\text { West }}$ All

\section{Percent of Population That is Foreign}

1989

1991

1992

$1991-1993: 6$

$$
0.68 \%
$$

$0.87 \%$

$9.5 \%$

$8.8 \%$

$7.9 \%$

Number of Newspaper Incidents

462

594

1,056

Number of Serious Newspaper Incidents (Arson \& Murder)

$1991-1993: 6$

236

415

651

Number of Newspaper Incidents/100,000 Population

$1991-1993: 6$

3.13

0.91

1.32

Number of Newspaper Incidents/1,000 Foreigners ${ }^{b}$
$1991-1993: 6$
4.63
0.10
0.18

\section{Unemployment Rate}

1992

$14.3 \%$

$6.7 \%$

$8.1 \%$

Notes: a. Number of incidents is derived from newspaper clippings. All oth $r$ variables are from BfLR.

b. Foreigners is as of 1991. 
Table 2

Number of Crimes by Nationality of Victim and Foreign Shares

Crimes

(column percent in parentheses)
Origin Shares

\begin{tabular}{ccccc} 
East & West & Total & East & West \\
\hline $59(46)$ & $37(15)$ & $96(25)$ & 57.7 & 8.6
\end{tabular}

$16(12) \quad 15(6) \quad 31(8) \quad 21.3 \quad 4.3$

Romanian

$21(16)$

11 (4)

$32(8)$

$8.5 \quad 1.5$

former Soviet Union

20 (16)

$6(2)$

$26(7)$

$11.6 \quad 0.7$

Hungarian

$1(1)$

$0(0)$

$1(0)$

$9.3 \quad 0.8$

\begin{tabular}{lccccc} 
other & $2(2)$ & $5(2)$ & $6(2)$ & 7.0 & 1.4 \\
\hline Turkish & $10(8)$ & $100(40)$ & $110(29)$ & 0.8 & 30.8 \\
\hline Southern European & $3(2)$ & $26(10)$ & $29(8)$ & 2.8 & 32.9 \\
$\quad$ former Yugoslav & $3(2)$ & $14(6)$ & $17(5)$ & 2.0 & 13.4 \\
other & $0(0)$ & $12(5)$ & $12(3)$ & 0.7 & 19.5 \\
\hline Asian & $28(22)$ & $36(14)$ & $64(17)$ & 23.7 & 9.2 \\
$\quad$ Vietnamese & $20(16)$ & $8(3)$ & $28(7)$ & & \\
$\quad$ others & $8(6)$ & $28(11)$ & $36(10)$ & & \\
\hline African & $19(15)$ & $33(13)$ & $52(14)$ & 7.9 & 4.0 \\
\hline Latin American & $6(5)$ & $3(1)$ & $9(2)$ & 2.8 & 1.0 \\
\hline Western Countries & $0(0)$ & $1(0)$ & $1(0)$ & 3.1 & 12.4 \\
\hline German & $4(3)$ & $13(5)$ & $17(5)$ & $\cdots$ & $\cdots$ \\
\hline Total & $129(100)$ & $249(100)$ & $378(100)$ & 100.0 & 100.0 \\
\hline
\end{tabular}

Notes: Number of incidents is derived from newspaper clippings. Origin shares of foreigners are from the Statistisches Jahrbuch für die Bundesrepublik Deutschland. 
Table 3

Relative Anti-foreign Crime Regressions for all German Counties

(Standard errors in parentheses)

\begin{tabular}{|c|c|c|c|c|c|c|c|}
\hline & \multirow[b]{2}{*}{ Means } & \multicolumn{3}{|c|}{$\begin{array}{c}\text { Incidents per } 100,000 \\
\text { Residents }\end{array}$} & \multicolumn{3}{|c|}{$\begin{array}{c}\text { Incidents per } 1,000 \\
\text { Foreigners }\end{array}$} \\
\hline & & $(1)$ & (2) & (3) & (4) & $(5)$ & (6) \\
\hline Unemployment Rate & $9.5 \%$ & $\begin{array}{l}.156 \\
(.054)\end{array}$ & $\begin{array}{r}-.124 \\
(.085)\end{array}$ & $\begin{array}{r}-.116 \\
(.077)\end{array}$ & $\begin{array}{l}1.007 \\
(.291)\end{array}$ & $\begin{array}{r}-.329 \\
(.482)\end{array}$ & $\begin{array}{r}-.246 \\
(.476)\end{array}$ \\
\hline West & .60 & --- & $\begin{array}{r}-3.705 \\
(.866)\end{array}$ & $\begin{array}{r}-1.014 \\
(.892)\end{array}$ & $\cdots$ & $\begin{array}{r}-16.532 \\
(4.762)\end{array}$ & $\begin{array}{r}-9.304 \\
(5.421)\end{array}$ \\
\hline Km. to Western Border ${ }^{\mathrm{a}}$ & $\begin{array}{c}43.7 \\
\text { [east: } 110.3]\end{array}$ & ---- & --- & $\begin{array}{r}.024 \\
(.004)\end{array}$ & --- & --- & $\begin{array}{r}.061 \\
(.024)\end{array}$ \\
\hline Percent Foreign & $4.4 \%$ & $\begin{array}{r}-.051 \\
(.059)\end{array}$ & $\begin{array}{r}.031 \\
(.060)\end{array}$ & $\begin{array}{r}.066 \\
(.056)\end{array}$ & $\begin{array}{r}.431 \\
(.354)\end{array}$ & $\begin{array}{r}.760 \\
(.359)\end{array}$ & $\begin{array}{r}.752 \\
(.355)\end{array}$ \\
\hline Log Population Density & 5.4 & $\begin{array}{r}-.433 \\
(.303)\end{array}$ & $\begin{array}{r}-.407 \\
(.299)\end{array}$ & $\begin{array}{r}-.363 \\
(.292)\end{array}$ & $\begin{array}{r}-8.205 \\
(2.021)\end{array}$ & $\begin{array}{r}-7.713 \\
(1.998)\end{array}$ & $\begin{array}{r}-7.556 \\
(1.984)\end{array}$ \\
\hline Moderately Urban & .36 & $\begin{array}{r}-.324 \\
(.428)\end{array}$ & $\begin{array}{r}-.186 \\
(.414)\end{array}$ & $\begin{array}{r}-.313 \\
(.401)\end{array}$ & $\begin{array}{r}-2.855 \\
(2.476)\end{array}$ & $\begin{array}{r}-2.310 \\
(2.430)\end{array}$ & $\begin{array}{r}-1.940 \\
(2.567)\end{array}$ \\
\hline Moderately Rural & .12 & $\begin{array}{r}.728 \\
(.602)\end{array}$ & $\begin{array}{r}.697 \\
(.583)\end{array}$ & $\begin{array}{r}.284 \\
(.558)\end{array}$ & $\begin{array}{r}4.633 \\
(3.572)\end{array}$ & $\begin{array}{r}4.274 \\
(3.504)\end{array}$ & $\begin{array}{r}4.120 \\
(3.612)\end{array}$ \\
\hline Rural & .18 & $\begin{array}{r}.514 \\
(.586)\end{array}$ & $\begin{array}{r}.802 \\
(.573)\end{array}$ & $\begin{array}{r}.353 \\
(.564)\end{array}$ & $\begin{array}{r}1.137 \\
(3.494)\end{array}$ & $\begin{array}{r}2.772 \\
(3.463)\end{array}$ & $\begin{array}{r}2.528 \\
(3.678)\end{array}$ \\
\hline $\begin{array}{l}\text { Kreisstadt (county is single } \\
\text { city) }\end{array}$ & .22 & $\begin{array}{r}1.592 \\
(.688)\end{array}$ & $\begin{array}{r}1.466 \\
(.680)\end{array}$ & $\begin{array}{l}1.388 \\
(.664)\end{array}$ & $\begin{array}{r}12.960 \\
(4.584)\end{array}$ & $\begin{array}{r}11.983 \\
(4.537)\end{array}$ & $\begin{array}{r}11.524 \\
(4.505)\end{array}$ \\
\hline $\begin{array}{l}\text { Travel Time to Metro Area } \\
\text { (minutes) }\end{array}$ & 84.0 & ---- & --.- & $\begin{array}{r}.011 \\
(.004)\end{array}$ & ---- & ---- & $\begin{array}{r}-.001 \\
(.028)\end{array}$ \\
\hline $\begin{array}{l}\text { Spatial autocorrelation } \\
\text { parameter }(\lambda)\end{array}$ & & $\begin{array}{r}.385 \\
(.051)\end{array}$ & $\begin{array}{r}.340 \\
(.053)\end{array}$ & $\begin{array}{r}.215 \\
(.059)\end{array}$ & $\begin{array}{r}.094 \\
(.056)\end{array}$ & $\begin{array}{r}.074 \\
(.057)\end{array}$ & $\begin{array}{r}.047 \\
(.058)\end{array}$ \\
\hline Number of observations & 543 & 543 & 543 & 543 & 541 & 541 & 541 \\
\hline
\end{tabular}

${ }^{a}$ This variable equals the distance from center of the county to the western border ignoring West Berlin, and 0 for western counties.

Note: All regressions estimated by Maximum Likelihood, allowing for spatial autocorrelation in the errors. All models also include a constant. 
Table 4

Relative Anti-foreign Crime Regressions for East and West Germany

(Standard errors in parentheses)

\begin{tabular}{|c|c|c|c|c|c|c|c|c|}
\hline & \multicolumn{4}{|c|}{ Incidents per 100,000 Residents } & \multicolumn{4}{|c|}{ Incidents per 1,000 Foreigners } \\
\hline & $\begin{array}{r}\text { East } \\
(1)\end{array}$ & $\begin{array}{r}\text { West } \\
(2)\end{array}$ & $\begin{array}{r}\text { East } \\
(3)\end{array}$ & $\begin{array}{r}\text { West } \\
(4)\end{array}$ & $\begin{array}{r}\text { East } \\
(5)\end{array}$ & $\begin{array}{r}\text { West } \\
(6)\end{array}$ & $\begin{array}{r}\text { East } \\
(7)\end{array}$ & $\begin{array}{r}\text { West } \\
(8)\end{array}$ \\
\hline Unemployment Rate & $\begin{array}{r}-.369 \\
(.181)\end{array}$ & $\begin{array}{r}-.046 \\
(.044)\end{array}$ & $\begin{array}{r}-.383 \\
(.167)\end{array}$ & $\begin{array}{r}-.028 \\
(.045)\end{array}$ & $\begin{array}{r}-3.277 \\
(1.168)\end{array}$ & $\begin{array}{r}.003 \\
(.009)\end{array}$ & $\begin{array}{r}-3.336 \\
(1.135)\end{array}$ & $\begin{array}{r}.005 \\
(.009)\end{array}$ \\
\hline Km. to Western Border & --- & -- & $\begin{array}{r}.020 \\
(.005)\end{array}$ & --- & --- & $-\cdots$ & $\begin{array}{r}.072 \\
(.035)\end{array}$ & --- \\
\hline Percent Foreign & $\begin{array}{l}2.642 \\
(.958)\end{array}$ & $\begin{array}{r}-.032 \\
(.028)\end{array}$ & $\begin{array}{r}1.982 \\
(.957)\end{array}$ & $\begin{array}{r}-.032 \\
(.031)\end{array}$ & $\begin{array}{r}-13.529 \\
(6.752)\end{array}$ & $\begin{array}{r}-.013 \\
(.006)\end{array}$ & $\begin{array}{r}-17.314 \\
(6.957)\end{array}$ & $\begin{array}{r}-.014 \\
(.006)\end{array}$ \\
\hline Log Population Density & $\begin{array}{l}-1.595 \\
(.784)\end{array}$ & $\begin{array}{r}.027 \\
(.170)\end{array}$ & $\begin{array}{r}-1.386 \\
(.745)\end{array}$ & $\begin{array}{r}-.054 \\
(.177)\end{array}$ & $\begin{array}{r}-10.095 \\
(5.215)\end{array}$ & $\begin{array}{r}-.046 \\
(.034)\end{array}$ & $\begin{array}{r}-8.552 \\
(5.177)\end{array}$ & $\begin{array}{r}-.057 \\
(.036)\end{array}$ \\
\hline Moderately Urban & $\begin{array}{r}-.089 \\
(.954)\end{array}$ & $\begin{array}{r}-.6763 \\
(.196)\end{array}$ & $\begin{array}{r}-.016 \\
(.871)\end{array}$ & $\begin{array}{r}-.673 \\
(.195)\end{array}$ & $\begin{array}{r}-4.816 \\
(6.086)\end{array}$ & $\begin{array}{r}-.136 \\
(.040)\end{array}$ & $\begin{array}{r}-4.587 \\
(5.900)\end{array}$ & $\begin{array}{r}-.137 \\
(.040)\end{array}$ \\
\hline Moderately Rural & $\begin{array}{r}2.852 \\
(1.482)\end{array}$ & $\begin{array}{r}-.781 \\
(.262)\end{array}$ & $\begin{array}{r}2.500 \\
(1.397)\end{array}$ & $\begin{array}{r}-.730 \\
(.260)\end{array}$ & $\begin{array}{r}19.921 \\
(9.855)\end{array}$ & $\begin{array}{r}-.162 \\
(.053)\end{array}$ & $\begin{array}{r}18.414 \\
(9.663)\end{array}$ & $\begin{array}{r}-.156 \\
(.053)\end{array}$ \\
\hline Rural & $\begin{array}{r}1.917 \\
(1.324)\end{array}$ & $\begin{array}{r}-.891 \\
(.285)\end{array}$ & $\begin{array}{r}1.509 \\
(1.248)\end{array}$ & $\begin{array}{r}-.855 \\
(.284)\end{array}$ & $\begin{array}{r}5.903 \\
(8.800)\end{array}$ & $\begin{array}{r}-.120 \\
(.058)\end{array}$ & $\begin{array}{r}4.295 \\
(8.641)\end{array}$ & $\begin{array}{r}-.115 \\
(.058)\end{array}$ \\
\hline $\begin{array}{l}\text { Kreisstadt (county is single } \\
\text { city) }\end{array}$ & $\begin{array}{r}3.868 \\
(2.229)\end{array}$ & $\begin{array}{r}.629 \\
(.302)\end{array}$ & $\begin{array}{r}3.515 \\
(2.123)\end{array}$ & $\begin{array}{r}.662 \\
(.313)\end{array}$ & $\begin{array}{r}21.941 \\
(14.914)\end{array}$ & $\begin{array}{r}.144 \\
(.061)\end{array}$ & $\begin{array}{r}18.970 \\
(14.736)\end{array}$ & $\begin{array}{r}.145 \\
(.063)\end{array}$ \\
\hline Travel time to Metro Area & $\begin{array}{r}.014 \\
(.009)\end{array}$ & $\begin{array}{r}.005 \\
(.002)\end{array}$ & $\begin{array}{r}.019 \\
(.008)\end{array}$ & $\begin{array}{r}.005 \\
(.002)\end{array}$ & $\begin{array}{r}.042 \\
(.059)\end{array}$ & $\begin{array}{r}.001 \\
(.0005)\end{array}$ & $\begin{array}{r}.065 \\
(.058)\end{array}$ & $\begin{array}{r}.001 \\
(.0005)\end{array}$ \\
\hline Fraction Low Qualifications & ---- & --- & --- & $\begin{array}{r}-.028 \\
(.023)\end{array}$ & --- & --- & $\cdots$ & $\begin{array}{r}-.005 \\
(.005)\end{array}$ \\
\hline Fraction High Qualifications & --- & --- & $-\cdots$ & $\begin{array}{r}-.010 \\
(.052)\end{array}$ & --- & --- & $-\cdots$ & $\begin{array}{r}-.002 \\
(.011)\end{array}$ \\
\hline Fraction Young Adults & ---- & --- & --- & $\begin{array}{r}.027 \\
(.043)\end{array}$ & ---- & ---- & --- & $\begin{array}{r}.001 \\
(.009)\end{array}$ \\
\hline Log Manufacturing Wage & --- & --- & --- & $\begin{array}{r}.378 \\
(.671)\end{array}$ & ---- & --- & $\cdots$ & $\begin{array}{r}.082 \\
(.137)\end{array}$ \\
\hline $\begin{array}{l}\text { Spatial autocorrelation } \\
\text { parameter }(\lambda)\end{array}$ & $\begin{array}{r}.191 \\
(.099)\end{array}$ & $\begin{array}{r}.228 \\
(.082)\end{array}$ & $\begin{array}{r}.068 \\
(.104)\end{array}$ & $\begin{array}{r}.193 \\
(.087)\end{array}$ & $\begin{array}{r}-.001 \\
(.095)\end{array}$ & $\begin{array}{r}.241 \\
(.074)\end{array}$ & $\begin{array}{l}-.045 \\
(.098)\end{array}$ & $\begin{array}{l}0.222 \\
(.077)\end{array}$ \\
\hline $\mathrm{N}$ & 215 & 328 & 215 & 328 & 213 & 328 & 213 & 328 \\
\hline
\end{tabular}

'This variable equals the distance from center of the county to the western border ignoring West Berlin, and 0 for western counties.

Note: All regressions estimated by Maximum Likelihood, allowing for spatial autocorrelation in the errors. All models also include a constant. 
Table 5

Regressions for Serious (Murder and Arson) Crime Rates

(Standard errors in parentheses)

\begin{tabular}{|c|c|c|c|c|c|c|c|c|}
\hline & \multicolumn{4}{|c|}{ Incidents per 100,000 Residents } & \multicolumn{4}{|c|}{ Incidents per 1,000 Foreigners } \\
\hline & $\begin{array}{r}\text { East } \\
(1)\end{array}$ & $\begin{array}{r}\text { West } \\
(2)\end{array}$ & $\begin{array}{r}\text { East } \\
(3)\end{array}$ & $\begin{array}{r}\text { West } \\
(4)\end{array}$ & $\begin{array}{r}\text { East } \\
(5)\end{array}$ & $\begin{array}{r}\text { West } \\
(6)\end{array}$ & $\begin{array}{r}\text { East } \\
(7)\end{array}$ & $\begin{array}{r}\text { West } \\
(8)\end{array}$ \\
\hline Unemployment Rate & $\begin{array}{r}-.184 \\
(.102)\end{array}$ & $\begin{array}{r}-.042 \\
(.029)\end{array}$ & $\begin{array}{r}-.182 \\
(.096)\end{array}$ & $\begin{array}{r}-.035 \\
(.031)\end{array}$ & $\begin{array}{r}-1.708 \\
(.580)\end{array}$ & $\begin{array}{r}-.000 \\
(.006)\end{array}$ & $\begin{array}{r}-1.726 \\
(.562)\end{array}$ & $\begin{array}{r}-.001 \\
(.006)\end{array}$ \\
\hline Km. to Western Border & --- & --- & $\begin{array}{r}.011 \\
(.003)\end{array}$ & --- & --- & --- & $\begin{array}{r}.040 \\
(.018)\end{array}$ & $-\cdots$ \\
\hline Percent Foreign & $\begin{array}{r}.894 \\
(.496)\end{array}$ & $\begin{array}{r}-.024 \\
(.019)\end{array}$ & $\begin{array}{r}.683 \\
(.499)\end{array}$ & $\begin{array}{r}-.028 \\
(.022)\end{array}$ & $\begin{array}{r}-6.850 \\
(3.280)\end{array}$ & $\begin{array}{r}-.009 \\
(.004)\end{array}$ & $\begin{array}{r}-8.610 \\
(3.339)\end{array}$ & $\begin{array}{r}-.010 \\
(.005)\end{array}$ \\
\hline Log Population Density & $\begin{array}{r}-.353 \\
(.417)\end{array}$ & $\begin{array}{r}.097 \\
(.123)\end{array}$ & $\begin{array}{r}-.263 \\
(.404)\end{array}$ & $\begin{array}{r}.055 \\
(.128)\end{array}$ & $\begin{array}{r}-3.386 \\
(2.551)\end{array}$ & $\begin{array}{r}-.018 \\
(.025)\end{array}$ & $\begin{array}{r}-2.589 \\
(2.528)\end{array}$ & $\begin{array}{r}-.021 \\
(.026)\end{array}$ \\
\hline Moderately Urban & $\begin{array}{r}-.086 \\
(.549)\end{array}$ & $\begin{array}{r}-.414 \\
(.135)\end{array}$ & $\begin{array}{r}.115 \\
(.509)\end{array}$ & $\begin{array}{r}-.406 \\
(.135)\end{array}$ & $\begin{array}{r}-0.923 \\
(3.039)\end{array}$ & $\begin{array}{r}-.085 \\
(.027)\end{array}$ & $\begin{array}{r}-.861 \\
(2.936)\end{array}$ & $\begin{array}{r}-.083 \\
(.027)\end{array}$ \\
\hline Moderately Rural & $\begin{array}{l}1.694 \\
(.815)\end{array}$ & $\begin{array}{r}-.464 \\
(.179)\end{array}$ & $\begin{array}{r}1.592 \\
(.778)\end{array}$ & $\begin{array}{r}-.433 \\
(.180)\end{array}$ & $\begin{array}{r}9.842 \\
(4.842)\end{array}$ & $\begin{array}{r}-.102 \\
(.036)\end{array}$ & $\begin{array}{r}9.174 \\
(4.734)\end{array}$ & $\begin{array}{r}-.100 \\
(.036)\end{array}$ \\
\hline Rural & $\begin{array}{l}1.144 \\
(.734)\end{array}$ & $\begin{array}{r}-.578 \\
(.198)\end{array}$ & $\begin{array}{r}.928 \\
(.701)\end{array}$ & $\begin{array}{r}-.565 \\
(.198)\end{array}$ & $\begin{array}{r}4.846 \\
(4.331)\end{array}$ & $\begin{array}{r}-.071 \\
(.040)\end{array}$ & $\begin{array}{r}3.915 \\
(4.225)\end{array}$ & $\begin{array}{r}-.071 \\
(.040)\end{array}$ \\
\hline $\begin{array}{l}\text { Kreisstadt (county is single } \\
\text { city) }\end{array}$ & $\begin{array}{r}1.139 \\
(1.196)\end{array}$ & $\begin{array}{r}.324 \\
(.219)\end{array}$ & $\begin{array}{r}1.044 \\
(1.158)\end{array}$ & $\begin{array}{r}.324 \\
(.226)\end{array}$ & $\begin{array}{r}7.019 \\
(7.286)\end{array}$ & $\begin{array}{r}.073 \\
(.044)\end{array}$ & $\begin{array}{r}5.572 \\
(7.182)\end{array}$ & $\begin{array}{r}.067 \\
(.045)\end{array}$ \\
\hline Travel time to Metro Area & $\begin{array}{r}.006 \\
(.006)\end{array}$ & $\begin{array}{r}.004 \\
(.002)\end{array}$ & $\begin{array}{r}.009 \\
(.005)\end{array}$ & $\begin{array}{r}.004 \\
(.002)\end{array}$ & $\begin{array}{r}.019 \\
(.030)\end{array}$ & $\begin{array}{r}.0007 \\
(.0003)\end{array}$ & $\begin{array}{r}.033 \\
(.029)\end{array}$ & $\begin{array}{r}.0006 \\
(.0003)\end{array}$ \\
\hline $\begin{array}{l}\text { Fraction Low } \\
\text { Qualifications }\end{array}$ & ---- & --- & ---- & $\begin{array}{r}-.009 \\
(.016)\end{array}$ & ---- & --- & ---- & $\begin{array}{r}-.001 \\
(.003)\end{array}$ \\
\hline $\begin{array}{l}\text { Fraction High } \\
\text { Qualifications }\end{array}$ & ---- & ---- & ---- & $\begin{array}{r}.026 \\
(.038)\end{array}$ & ---- & --- & ---- & $\begin{array}{r}.005 \\
(.008)\end{array}$ \\
\hline Fraction Young Adults & $-\cdots$ & ---- & --- & $\begin{array}{r}.005 \\
(.030)\end{array}$ & --- & --- & $-\cdots$ & $\begin{array}{r}-.003 \\
(.006)\end{array}$ \\
\hline Log Manufacturing Wage & ---- & $-\cdots$ & --- & $\begin{array}{r}.036 \\
(.482)\end{array}$ & --- & --- & $\cdots$ & $\begin{aligned}-.001 \\
(.098)\end{aligned}$ \\
\hline $\begin{array}{l}\text { Spatial autocorrelation } \\
\text { parameter }(\lambda)\end{array}$ & $\begin{array}{r}.350 \\
(.090)\end{array}$ & $\begin{array}{r}.093 \\
(.091)\end{array}$ & $\begin{array}{r}.243 \\
(.098)\end{array}$ & $\begin{array}{r}.074 \\
(.094)\end{array}$ & $\begin{array}{r}.060 \\
(.085)\end{array}$ & $\begin{array}{r}.090 \\
(.083)\end{array}$ & $\begin{array}{r}.014 \\
(.087)\end{array}$ & $\begin{array}{r}.078 \\
(.084)\end{array}$ \\
\hline $\mathrm{N}$ & 215 & 328 & 215 & 328 & 213 & 328 & 213 & 328 \\
\hline
\end{tabular}

${ }^{a}$ This variable equals the distance from center of the county to the western border ignoring West Berlin, and 0 for western counties.

Note: All regressions estimated by Maximum Likelihood, allowing for spatial autocorrelation in the errors. All models also include a constant. 
Table 6

Alternative Maximum Likelihood Models for the Total

Number of Incidents of Crime Against Foreigners

(Standard errors in parentheses)

\begin{tabular}{|c|c|c|c|c|}
\hline & \multicolumn{2}{|c|}{ Poisson } & \multicolumn{2}{|c|}{$\begin{array}{l}\text { Negative } \\
\text { Binomial }\end{array}$} \\
\hline & $\begin{array}{r}\text { East } \\
(1)\end{array}$ & $\begin{array}{r}\text { West } \\
(2)\end{array}$ & $\begin{array}{r}\text { East } \\
(3)\end{array}$ & $\begin{array}{r}\text { West } \\
(4)\end{array}$ \\
\hline Unemployment Rate & $\begin{array}{r}-.117 \\
(.028)\end{array}$ & $\begin{array}{r}-.038 \\
(.027)\end{array}$ & $\begin{array}{r}-.121 \\
(.041)\end{array}$ & $\begin{array}{r}-.052 \\
(.043)\end{array}$ \\
\hline Km. to Western Border & $\begin{array}{r}.004 \\
(.001)\end{array}$ & ---- & $\begin{array}{r}.004 \\
(.001)\end{array}$ & --- \\
\hline Percent Foreign & $\begin{array}{r}.320 \\
(.132)\end{array}$ & $\begin{array}{r}-.019 \\
(.016)\end{array}$ & $\begin{array}{r}.346 \\
(.222)\end{array}$ & $\begin{array}{r}.019 \\
(.025)\end{array}$ \\
\hline Log Population & $\begin{array}{r}.772 \\
(.122)\end{array}$ & $\begin{array}{r}1.175 \\
(.071)\end{array}$ & $\begin{array}{r}1.103 \\
(.216)\end{array}$ & $\begin{array}{r}1.164 \\
(.144)\end{array}$ \\
\hline Log Population Density & $\begin{array}{r}-.355 \\
(.136)\end{array}$ & $\begin{array}{r}-.007 \\
(.120)\end{array}$ & $\begin{array}{r}-.532 \\
(.213)\end{array}$ & $\begin{array}{r}.009 \\
(.187)\end{array}$ \\
\hline Moderately Urban & $\begin{array}{r}.222 \\
(.149)\end{array}$ & $\begin{array}{r}-.517 \\
(.130)\end{array}$ & $\begin{array}{r}.138 \\
(.231)\end{array}$ & $\begin{array}{r}-.592 \\
(.181)\end{array}$ \\
\hline Moderately Rural & $\begin{array}{r}.440 \\
(.229)\end{array}$ & $\begin{array}{r}-.763 \\
(.212)\end{array}$ & $\begin{array}{r}.386 \\
(.349)\end{array}$ & $\begin{array}{r}-.846 \\
(.276)\end{array}$ \\
\hline Rural & $\begin{array}{r}.685 \\
(.206)\end{array}$ & $\begin{array}{r}-1.002 \\
(.250)\end{array}$ & $\begin{array}{r}.566 \\
(.307)\end{array}$ & $\begin{array}{r}-1.009 \\
(.317)\end{array}$ \\
\hline $\begin{array}{l}\text { Kreisstadt (city is single } \\
\text { county) }\end{array}$ & $\begin{array}{r}1.037 \\
(.343)\end{array}$ & $\begin{array}{r}.543 \\
(.207)\end{array}$ & $\begin{array}{l}1.295 \\
(.549)\end{array}$ & $\begin{array}{r}.594 \\
(.349)\end{array}$ \\
\hline $\begin{array}{l}\text { Travel Time to Metro } \\
\text { Area (minutes) }\end{array}$ & $\begin{array}{r}.003 \\
(.001)\end{array}$ & $\begin{array}{r}.007 \\
(.001)\end{array}$ & $\begin{array}{r}.003 \\
(.002)\end{array}$ & $\begin{array}{r}.007 \\
(.002)\end{array}$ \\
\hline $\begin{array}{l}\text { Test of Poisson } \\
\text { restrictions [p-value] }\end{array}$ & $\ldots$ & --- & $\begin{array}{r}72.7 \\
{[.000]}\end{array}$ & $\begin{array}{r}103.5 \\
{[.000]}\end{array}$ \\
\hline Pseudo $\mathrm{R}^{2}$ & 0.225 & .379 & .097 & .143 \\
\hline $\mathbf{N}$ & 215 & 328 & 215 & 328 \\
\hline
\end{tabular}

${ }^{a}$ This variable equals the distance from center of the county to the western border ignoring West Berlin, and 0 for western counties.

All models also include a constant. 